\title{
SISTEM BAGI HASIL SIMPANAN PADA KOPERASI SYARI'AH BMT ASY-SYABAAB BKPRMI KAB. PINRANG
}

\author{
Muhammad Nasri Katman, \\ Prodi Ekonomi Islam UIN Alauddin Makassar, \\ Muh.nasri@uin-alauddin.ac.id \\ Syarifuddin, \\ Prodi Ekonomi Islam UIN Alauddin Makassar \\ syarifuddin7890@gmail.com
}

\begin{abstract}
This research was conducted with the aim of analyzing the savings-share system at the Shari'ah Cooperative BMT Asy-Shabaab BKPRMI Kab. Pinrang. This research is descriptive research. Descriptive research is a study that aims to provide or describe a current state or phenomenon by using scientific procedures to answer the problem in real time.

Based on the results of the research found that the Deposit Procedure in The Shari'ah Cooperative BMT Asy-Syabaab BKPRMI is carried out with several stages such as filling out the Form. The Revenue Sharing system and its calculations are implemented by the Shari'ah Cooperative BMT Asy-Syabaab BKPRMI on Savings which is a profit sharing method that corresponds to Fatwa DSN No.15/DSN-MUI/IX/2000 in The Distribution of Results. While in the determination of the distribution of the revenue sharing ratio has been determined by BMT and the Customer (Agreement). Income share of Savings is always different, depending on the amount of savings balance and BMT profit, because the amount of savings balance and BMT profit is always changed every month.
\end{abstract}

Keywords : Savings Fund, Savings Share

\begin{abstract}
Abstrak
Penelitian ini dilakukan dengan tujuan Untuk Menganalisis sistem bagi hasil simpanan pada Koperasi Syari'ah BMT Asy-Syabaab BKPRMI Kab. Pinrang. penelitian ini adalah penelitian deskriptif. Penelitian deskriptif adalah sebuah penelitian yang bertujuan untuk memberikan atau menjabarkan suatu keadaan atau fenomena yang terjadi saat ini dengan menggunakan prosedur ilmiah untuk menjawab masalah secara aktual.

Berdasarkan Hasil Penelitian ditemukan bahwa Prosedur Simpanan di Koperasi Syari'ah BMT Asy-Syabaab BKPRMI dilakukan dengan beberapa tahap seperti mengisi Formulir. Sistem Bagi Hasil dan Perhitungannya yang diterapkan oleh Koperasi Syari'ah BMT Asy-Syabaab BKPRMI pada Simpanan yaitu metode Profit sharing yang sesuai dengan Fatwa DSN No.15/DSN-MUI/IX/2000 Dalam Pembagian Hasil. Sedangkan dalam penetapan pembagian Nisbah bagi hasil telah ditetapkan oleh BMT dan Nasabah (Kesepakatan). Pendapatan bagi hasil Simpanan selalu berbeda, tergantung pada jumlah saldo tabungan dan keuntungan BMT, karena besarnya saldo tabungan dan keuntungan BMT selalu berubah tiap bulannya.
\end{abstract}

\section{Kata kunci : Dana Simpanan, Bagi Hasil Simpanan}

\section{PENDAHULUAN}

Perkembangan ekonomi syariah di indonesia sangat pesat. Mulai dari perkebangan sektor perbankan syariah pada tahun 1992 ditandai dengan adanya undang-undang nomor 7 tahun 1992 
tentang perbankan syariah dengan menggunakan sistem bagi hasil. Kemudian mengalami perbaikan melalui Undang- nomor 10 tahun 1998 yang mengakui adanya bank berdasarkan prinsip syariah di samping bank konvensional, dan terakhir mengalami perubahan dengan undang-undang nomor 21 tahun 2008 tentang perbankan syariah.

Keberhasilan penerapan prinsip syariah pada perbankan syariah kemudian diikuti dengan upaya penerapan prinsip syariah ke dalam lembaga keuangan non bank seperti asuransi reksa dana, pasar modal serta lembaga pembiayaan dan koperasi. Baitul maal wat tanwil (BMT ) merupakan salah satu bentuk lembaga keuangan yang menerapkan prinsip syariah dengan status badan hukum koperasi.

Baitul Maal Wat at Tamwil (BMT) adalah lembaga keuagan mikro yang beroperasikan dengan prinsip bagi hasil, menumbuh-kembangkan bisnis usaha mikro dalam rangka mengangkat derajat dan martabat serta membela kepentingan kaum fakir miskin, ditumbuhkan atas prakarsa dan modal awal dari tokoh-tokoh mayarakat setempat dengan berlandaskan pada sistem ekonomi yang salam: keselamatan (berintikan keadilan), kedamaian, dan kesejahteraan (Sumar'in $2012: 45$ ).

Baitul Mal Wat Tamwil (BMT) tersusun atas dua kata golongan yang masing-masing mempunyai makna sendiri, yakni Baitul Maal dan Baituttamwil. Baitul Maal adalah lembaga keuangan yang berorientasi sosial keagamaan yang kegiatan utamanya menampung serta menyalurkan harta masyarakat berupa zakat, infaq, dan shodaqoh (ZIS), sesuai dengan ketentuan prinsip syariah. Sedangkan baituttamwil adalah lembaga keuangan yang kegiatan utamanya menghimpun dana dari masyarakat dalam bentuk simpanan dan menyalurkannya kembali dalam bentuk pembiayaan berdasarkan prinsip syariah (ahmad Syifaul Anam 2012 : 37)

Peran BMT hampir mirip dengan bank iyatu, sebagai meditor keuangan iyaitu menarik dana dari masyarakat dalam bentuk Simpanan dan menyalurkannya kembali ke masyarakat dalam bentuk pembiayaan. BMT bersifat terbuka, independen, berorientasi pada pengembangan tabungan dan pembiayaan untuk mendukung bisnis ekonomi yang produktif bagi anggota dan kesejahteraan sosial masyarakat sekitar terutama usaha mikro dan fakir miskin.

Fungsi BMT, yaitu(1) mengidentifikasi, memobilisasi, mengorganisir, mendorong dan mengembangan potensi serta kemampuan ekonomi anggota,(2) mempertingi kualitas SDM anggota agar menjadi lebih professional dan islami, (3) mengalang dan mengorganisir potensi masyarakat dalam rangka meningkatkan kesejahteraan anggota.(Muhammad Ridwan,2004:124)

beberapa hasil penelitian- penelitian sebelumnya yang terkait dengan Sistem bagi hasil. diantaranya Esy Nur Aisyah (2008) mengemukakan bahwa BMT memberikan kemudahan kepada anggota koperasi dalam melakukan transaksi tabungan. tabungan mudharabah dan mudharabah berjangka adalah mengacu pada prinsip profit sharing. Kemudian dalam penetapan pembagian Nisbah bagi hasil, tidak ada kesepakatan antara Nasabah (shahibul maal) dengan BMT (mudharib). Akan tetapi Nisbah ditetapkan oleh BMT MMU cabang Wonorejo. Syamsul Ma'arif (2009) mengemukakan bahwa sistem transaksi tabungan mudharabah di BRI Syari'ah cabang Malang menggunakan akad mudharabah mutlaqah, Sistem bagi hasil yang diterapkan BRI Syari'ah cabang Malang pada tabungan mudharabah adalah mengacu pada prinsip revenue sharing.

Menurut Kashmir (2009:78) menyatakan bahwa Tabungan adalah simpanan pihak ketiga dalam bentuk rupiah maupun valuta asing pada bank yang penarikannya hanya dapat dilakukan menurut syarat tertentu dari masing - masing bank penerbit. Menurut Antonio (2001:155) menyatakan bahwa tabungan mudharabah adalah tabungan yang menerapkan akad mudharabah, diantaranya adalah keuntungan dari dana yang digunakan harus dibagi antara Nasabah (shahibul maal) dan bank (mudharib) 
Prinsip tabungan yang digunakan oleh Koperasi Syari'ah BMT Asy-Syabaab BKPRMI Kab. Pinrang adalah akad mudharabah. Produk tabungan mudharabah yang di tawarkan BMT kepada masyarakat yaitu tabungan umum mudharabah, dan mudharabah berjangka. Tabungan mudharabah yang paling diminati anggota adalah tabungan umum mudharabah yang mempunyai prosentase hampir $100 \%$ dari pada tabungan mudharabah berjangka. Koperasi Syari'ah BMT Asy-Syabaab BKPRM sebagai mudharib, dalam mendapatkan keuntungan, mereka menyalurkan modal dari Nasabah (shahibul maal) kepada masyarakat yang membutuhkan dana melalui berbagai produk pembiayaan. Dan kemudian atas dasar prinsip bagi hasil, BMT sebagai mudharib dari penabung (shahibul maal), harus membagikan keuntungan yang diperolehnya kepada penabung. Dan dalam hal ini juga memerlukan mekanisme perhitungan bagi hasil antara BMT (mudharib) dan Penabung (shahibul maal).

Berdasarkan Iatar belakang di atas, maka peneliti melakukan penelitian mengenai Sistem Bagi Hasil Simpanan pada Koperasi Syari'ah BMT Asy-Syabaab BKPRMI Kab. Pinrang. Tujuan penelitian ini adalah untuk Menganalisis sistem bagi hasil simpanan pada Koperasi Syari'ah BMT Asy-Syabaab BKPRMI Kab. Pinrang

\section{KAJIAN LITERATUR}

\section{Pengertian Baitul Maul Wattamwil (BMT)}

Baitul Maal wat Tamwil (BMT) atau Balai Usaha Mandiri Terpadu, adalah lembaga keuangan mikro yang dioperasikan dengan prinsip bagi hasil, menumbuh kembangkan derajat dan martabat Serta membela kepentingan kaum fakir miskin, dan ditumbuhkan atas prakarsa dan modal awal dari tokoh-tokoh masyarakat setempat dengan berlandaskan pada sistem ekonomi yang Salam (Jeni susyanti, 2016).

\section{Dana Simpanan (Dana Pihak Ketiga)}

Berdasarkan ketentuan dalam Undang-Undang Nomor 7 Tahun 1992 tentang Perbankan maupun Undang-Undang perubahannya, bentuk penghimpunan dana dapat dilakukan melalui penerimaan Simpanan dari masyarakat. Menurut Kashmir (2003) simpanan adalah dana yang dipercayakan oleh masyarakat kepada bank dalam bentuk giro, deposito berjangka, sertifikat deposito tabungan atau yang dapat dipersamakan dengan itu.

\section{Pengertian Bagi Hasil}

Menurut Antonio (2001), bagi hasil adalah suatu Sistem pengolahan dana dalam perekonomian Islm yakni pembagian hasil usaha antara pemilik modal (shahibul maab dan pengelola (mudharib). Dengan demikian dari kedua pendapat tersebut dapat diambil kesimpulan bahwa bagi hasil adalah suatu system pengelolaan dana dalam pembagian hasil usaha dapat terjadi antara bank dan penyimpan dana.

\section{METODE PENELITIAN}

Jenis penelitian ini adalah penelitian deskriptif. Seperti yang dikemukakan oleh Sugiyono (2011), penelitian deskriptif adalah sebuah penelitian yang bertujuan untuk memberikan atau menjabarkan suatu keadaan atau fenomena yang terjadi saat ini dengan menggunakan prosedur ilmiah untuk menjawab masalah secara aktual. Menurut Supardi (2005), penelitian deskriptif secara garis besar merupakan kegiatan penelitian yang hendak membuat gambaran suatu peristiwa atau gejala secara sistematis, factual dengan penyusunan yang akurat. Berdasarkan uraian tersebut dapat dikemukakan bahwa penelitian deskriptif ini berusaha menggambarkan objek penelitian berdasarkan fakta dan data serta kejadian berusaha menghubungkan kejadiankejadian atau objek penelitian sekaligus menganalisanya berdasarkan konsep-konsep yang telah dikembangkan sebelumnya sehingga memudahkan peneliti dalam memecahkan masalah. Teknik 
pengumpulan data yang akan digunakan adalah: (1) Teknik Observasi, Teknik observasi dilakukan untuk mengetahui secara langsung kegiatan Koperasi Syari'ah BMT Asy-Syabaab BKPRMI serta pelayanannya terhadap Nasabah. 2. Teknik Dokumentasi Teknik dokumentasi digunakan untuk mengumpulkan data yang berkaitan dengan dana simpanan Nasabah dengan sistem bagi hasil pada Koperasi Syari'ah BMT Asy-Syabaab BKPRMI. (3) Teknik Wawancara, Teknik wawancara dilakukan untuk memperoleh informasi secara Iangsung dengan manager, kasir, pengelola keuangan, para pegawai dan pihak-pihak yang terkait dengan Koperasi Syari'ah BMT Asy-Syabaab BKPRMI tentang dana simpanan Nasabah dengan sistem bagi hasil pada BMT. Dalam menganalisis data yang sudah terkumpul peneliti akan menggunakan metode analisis deskriptif. Peneliti akan menjelaskan secara sistematis dan mendalam terhadap data yang telah dikumpulkan dalam bentuk penjelasan secara terperinci dalam bentuk kalimat kalimat yang tersusun secara sistematis.

\section{HASIL PENELITIAN DAN PEMBAHASAN}

\section{Dana Simpanan}

Berdasarkan data yang saya peroleh dari Bagian Administrasi/Keuangan, Jumlah Dana Simpanan Nasabah pada Koperasi Syari'ah BMT Asy-Syabaab BKPRMI mulai Tahun 2013 2016 adalah dapat dilihat pada table Berikut :

Tabel 1

Jumlah Simpanan

\begin{tabular}{|c|c|}
\hline Tahun & Jumlah Simpanan \\
\hline 2013 & 1.548 .695 .300 \\
\hline 2014 & 1.610 .158 .100 \\
\hline 2015 & 1.985 .432 .400 \\
\hline 2016 & 2.644 .736 .200 \\
\hline
\end{tabular}

Sumber: Bagian Administrasi/Keuangan Koperasi Syari'ah BMT Asy-Syabaab BKPRMI

Berdasarkan data di atas di tahun 2013. Jumlah dana simpanan nasabah Rp1.548.695.300, tahun 2014 dana simpanan nasabah Rp.1.610.158.100. tahun 2015 dana simpanan nasabah Rp.1.985.432.400 dan pada tahun 2016 dana simpanan nasabah sebesar Rp. 2.644.736.200 berdasarka data diatas menunjukkan bahwa Mulai tahun 2013 - 2016, jumlah dana simpanan Nasabah mengalami peningkatan. Pernyataan diatas Sesuai dengan penyataan Manager BMT :

Alhamdulilah secara keseluruhan Jumlah Simpana kami terus meningkat tahun ketahun mulai dari berdirinya BMT sampai sekarang.

\section{Sistem dan Prosedur Dana Simpanan pada Koperasi Syari'ah BMT Asy-Syabaab BKPRMI}

Tabungan pada Koperasi Syari'ah BMT Asy-Syabaab adalah simpanan dana dilakukan kapan saja, tetapi tidak dapat ditarik dengan menggunakan cek, bilyet giro, dan/atau alat Iainnya yang dipersamakan dengan itu. Sesuai dengan penyataan Manager BMT :

Tabungan Nasabah bisa di ambil kapan saja di kantor BMT dengan menggunakan Slip

Penarikan Simpanan dan BMT tidak Menerima Alat Penarikan yang lain. 
Tabungan yang ditawarkan oleh Koperasi Syari'ah BMT Asy-Syabaab BKPRMI adalah tabungan dengan prinsip/akad mudharabah yaitu bentuk kerja sama antara anggota (pemilik dana/shahibul maal) dan Koperasi Syari'ah BMT Asy-Syabaab BKPRMI (pengelola dana/mudharib) yang cakupannya sangat Iuas dan tidak dibatasi oleh jenis usaha, waktu dan daerah bisnis. Sesuai pernyataan Manager BMT :

\section{Tabungan di BMT kami adalah Tabungan Mudharabah}

Berdasarkan hasil wawancara dengan Manajer BMT dan Bagian Administrasi/Keuangan mengenai Skema Mudaharabah yang menyatakan :

Jika kita bicara skema tentunya kita mulai dari Nasabah yang menitipkan uangnya atau menabung ke BMT kami setelah itu kami la menyalurkan ke anggota yang membutuhkan pembiayaan atau Dunia Usaha Setalah itu BMT mendapatkan Bagi hasil Sehingga Sehingga Nasabah yang menitipkan uangnya di BMT kami akan mendapatkan Bagi Hasil dari BMT kami.

Skema Mudharabah yang diterapkan oleh Koperasi Syari'ah BMT Asy-Syabaab BKPRMI adalah dapat digambarkan sebagai berikut:

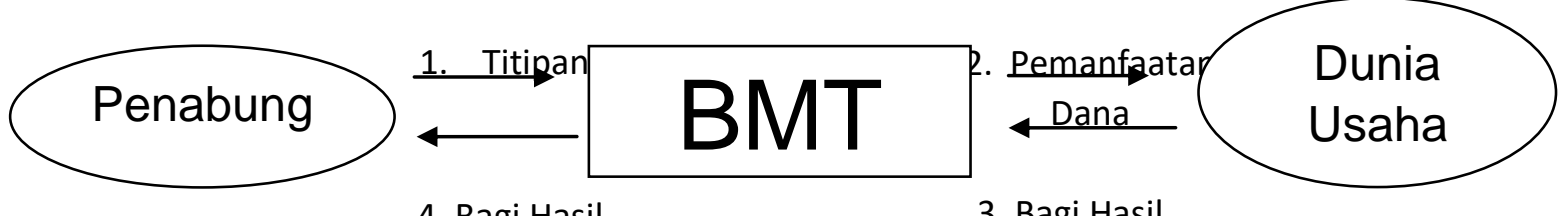

Sumber: Data diolah peneliti ( wawancara dengan manager BMT)

\section{Gambar 1 Skema Mudharabah}

Produk simpanan di Koperasi Syari'ah BMT Asy-Syabaab BKPRMI adalah Mudharabah, qurban, wadimah, pendidikan, aqiqah, hari raya, haji/umrah, dan Amanah Berjangka, sesuai pernyataan Manager BMT :

Produk Simpanan di BMT kami itu ada beberapa yaitu Simpanan Mudharabah, Simpanan Qurban, Simpanan Wadimah (Pernikahan), Simpanan Pendidikan, Simpanan Aqiqah, Simpanan Hari Raya, Simpanan Haji/Umrah Dan Simpanan Amanah Berjangka.

Sistem dan Jumlah Nasabah dari Produk Simpanan tersebut, dapat dilihat pada tabel berikut:

Tabel 2

Sistem Dan Jumlah Nasabah Simpanan

\begin{tabular}{|c|c|c|}
\hline Jenis Simpanan & Jumlah Nasabah & Sistem Simpanan \\
\hline Mudharabah & 536 & Bagi Hasil \\
\hline Qurban & 11 & Titipan \\
\hline Walimah & 1 & Titipan \\
\hline Pendidikan & 686 & Titipan \\
\hline Aqiqah & - & Titipan \\
\hline Hari Raya & - & Titipan \\
\hline
\end{tabular}




\begin{tabular}{|c|c|c|}
\hline Haji/Umrah & 210 & Titipan \\
\hline Amanah Berjangka & 2 & Bagi Hasil \\
\hline
\end{tabular}

Sumber: Data diolah peneliti (wawancara dengan Manager)

Berdasarkan hasil wawancara dengan manager BMT yang menyatakan bahwa adapun penjelasan tentang SOP Simpanan pada Koperasi Syari'ah BMT Asy-Syabaab BKPRMI adalah sebagai berikut:

a. Calon Nasabah mengisi formulir pendaftaran.

b. Calon Nasabah menyetor/menunjukkan fotocopy Kartu Tanda Penduduk (KTP)/Surat Izin Mengemudi (SIM).

c. Setoran awal minimal Rp. 50.000 kecuali produk haji/umrah minimal setoran Rp. 500.000 .

d. Bersedia mentaati aturan Koperasi Syari'ah BMT Asy-Syabaab BKPRMI.

Kegiatan menghimpun dana mulai dan sosialisasi aktifitas dan tujuan BMT, mendekati dan meyakinkan calon nasabah/mereka yang tertarik, memberikan formulir pendaftaran sebagai Nasabah, mengunjungi kembali setelah berselang beberapa hari, mengajak ke kantor BMT atau mengantarkan slip setoran (SS), menerima uang Nasabah, menyetor pada kasir dan memberikan buku tabungan (BT) kepada Nasabah yang bersangkutan. Sesuai penyataan BMT :

Untuk manarik Nasabah supaya ingin menitipkan uang di BMT kami selalu melakukan Sosialisasi aktifitas dan tujuan BMT ke kemasyarakat dan tempat ibadah sekaligus memberikan Formulir kami anggap sebagai calon Nasabah dan kami mendekati meyakinkan calon Nasabah sampai di ingin metitipkan uangnya di BMT kami.

Untuk Iebih jelasnya dapat dilihat pada gambar berikut :

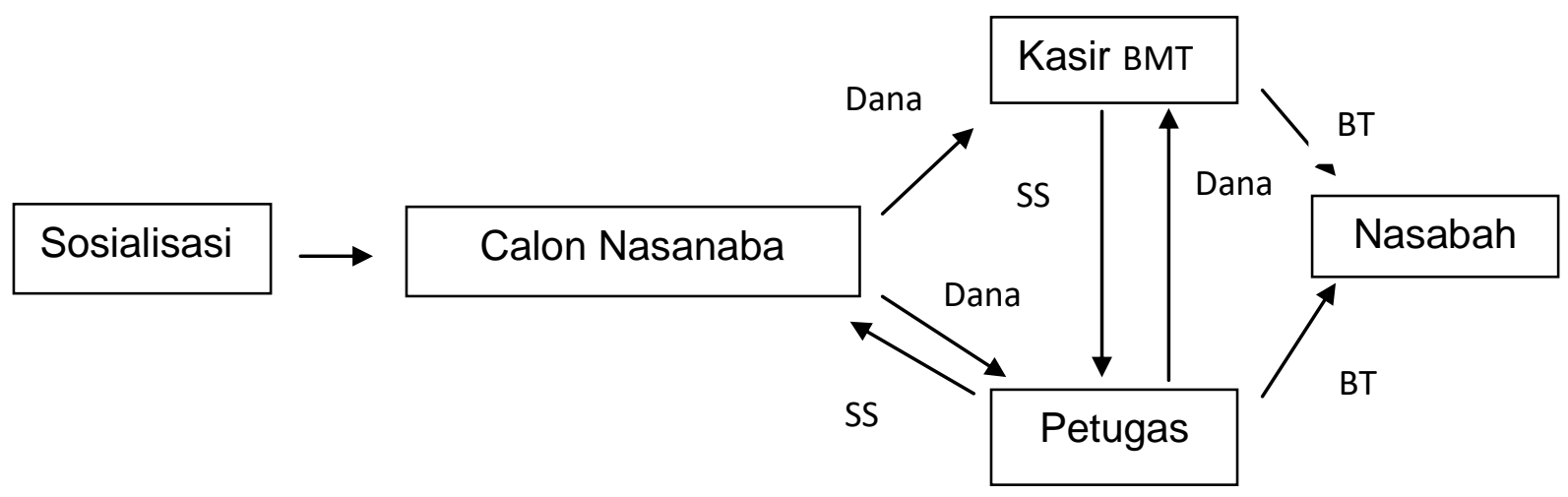

Gambar 2 Skema Sistem dan Prosedur Simpanan

\section{Analisis Metode Perhitungan Bagi Hasil Simpanan di Koperasi Syari'ah BMT Asy- Syabaab BKPRMI}

Berdasarkan hasil Wawancara dengan Manajer BMT Metode Perhitungan Bagi Hasil Simpanan Mudharabah Dan Amanah Berjangka yang digunakan Koperasi Syari'ah BMT AsySyabaab BKPRMI adalah profit sharing. Profit sharing merupakan Bagi Hasil yang dihitung dari pendapatan setelah dikurangi modal dan biaya-biaya. Dimana Nasabah memperoleh bagi hasil dari keuntungan bersih yang diperoleh Koperasi Syari'ah BMT Asy-Syabaab BKPRMI atas dikelolanya dana dari simpanan mudharabah. Sesuai pernyataan Manager BMT :

Metode perhitungan bagi hasil BMT kami berdasarkan laba bersih bukan laba kotor. 
Koperasi Syari'ah BMT Asy-Syabaab BKPRMI menggunakan metode profit sharing, dengan alasan sebagai berikut :

1. Konsep metode yang masih dipahami pihak Koperasi Syari'ah BMT Asy-Syabaab BKPRMI adalah profit sharing.

2. Profit sharing lebih menyimpan unsur keadilan, karena pada prakteknya memberikan tanggungjawab yang sama antara shahibul maal (Nasabah) dengan mudharib (Koperasi Syari'ah BMT Asy-Syabaab BKPRMI) dalam keuntungan dan begitu sebaliknya apabila ada kerugian.

3. Koperasi Syari'ah BMT Asy-Syabaab BKPRMI memberikan porsi keuntungan yang sebenarnya didapat oleh Nasabah.

Koperasi Syari'ah BMT Asy-Syabaab BKPRMI menerapkan Metode profit sharing, dimana bagi hasil diperoleh dari seluruh pendapatan, baik hasil investasi dana maupun pendapatan fee atas jasa-jasa yang diberikan oleh BMT setelah dikurangi biaya-biaya operasional BMT. Hal ini akan mempengaruhi bagi hasil yang diperoleh Shahibul Maal (Nasabah). Shahibul maal akan memperoleh bagi hasil yang lebih kecil dan akan berdampak pada jumlah Nasabah simpanan, karena berkurangnya keinginan Nasabah untuk menyimpan uangnya atau bahkan beralih menyimpan uangnya pada lembaga keuangan syariah lain. Sesui dengan pernyataan Manager BMT :

\section{Penyataan Pertama}

Bagi hasil yang didapat atau diberikan kepada Nasabah Simpanan berasal dari semua pendapatan BMT.

Pernyataan kedua

Yang menaggung biaya operasiol BMT tentunya nasabah dan BMT artinya bagi hasil yang di bagikan ke nasabah adalah laba bersi BMT bukan laba kotor BMT.

Sesuai dengan hasil wawancara dengan manager BMT Untuk menganalisis perhitungan bagi hasil simpanan di Koperasi Syari'ah BMT Asy-Syabaab BKPRMI maka peliti menggunakan data sebagai berikut :

\section{Contoh Perhitungan Bagi hasil Simpanan}

Pada bulan September tahun 2015, ada dua penabung di Koperasi Syari'ah BMT AsySyabaab BKPRMI yaitu A dan B dengan Jumlah saldo dalam 1 Bulan yang dimiliki penabung A sebesar Rp. 47.500.000,00.sedangkan penabung B memiliki Jumlah saldo dalam 1 Bulan sebesar Rp. 10.800.000,00. Persentase bagi hasil sebesar Rp. 177.800 didapat dari $20 \%$ pendapatan bulanan BMT sebesar Rp. 889.000 dan saldo rata rata Simpanan Rp. 30.334.000 Perbedaan jumlah saldo tersebut dapat mempengaruhi terhadap besarnya bagi hasil penabung $\mathrm{A}$ dan $\mathrm{B}$. Untuk Iebih jelasnya, dapat dilihat di bawah ini:

1. Saldo rata-rata simpanan

$$
\text { saldo rata }- \text { rata simpanan }=\frac{\text { Jumlah Saldo Dalam Satu Bulan }}{\text { Jumlah Hari Dalam Satu Bulan Tersebut }}
$$


saldo rata - rata simpanan $=\frac{46.060 .022}{30}=1.159 .431$

Penabung Nuno

$$
\text { saldo rata }- \text { rata simpanan }=\frac{10.649 .847}{30}=354.995
$$

2. Perhitungan Bagi Hasil

$$
\text { Bagi Hasil }=\frac{\text { Saldo Rata }- \text { rata }}{\text { Total Saldo Rata }- \text { rata }} \times(\text { Pendapatan BMT } \times \text { Nisba Bagi Hasil })
$$

Bagi Hail Penabung A

$$
\text { Bagi Hasil }=\frac{1.159 .431}{30.334 .000} \times(889.000 \times 20 \%)=6.796
$$

Bagi Hail Penabung B

$$
\text { Bagi Hasil }=\frac{354.995}{30.334 .000} \times(889.000 \times 20 \%)=2.080
$$

\section{Analisis Kesuaian Sistem Perhitungan Bagi Hasil Dana Simpanan Berdasarkan Fatwa Dewan Syariah Nasional (DSN)}

Peliti akan melakukan analisis yang berkaitan dengan kesesuaian metode perhitungan bagi hasil pada Simpanan berdasarkan Fatwa DSN Di Koperasi Syari'ah BMT Asy. Syabaab BKPRMI Pinrang.

Tabel 2

Analisis Kesesuaian Metode Perhitungan Bagi Hasil Pada Simpanan Berdasarkan Fatwa DSN Di Koperasi Syari'ah BMT Asy. Syabaab BKPRMI

\begin{tabular}{|l|l|l|l|l|}
\hline \multirow{2}{*}{ No } & $\begin{array}{c}\text { Item Dalam } \\
\text { Distribusi } \\
\text { Hasil } \\
\text { Usaha }\end{array}$ & $\begin{array}{l}\text { Implementasi Distribusi Hasil } \\
\text { Usaha }\end{array}$ & $\begin{array}{l}\text { Fatwa Dewan } \\
\text { Syariah Nasional } \\
\text { (DSN) }\end{array}$ & Kesesuaian \\
\hline 1 & $\begin{array}{l}\text { Nisba Bagi } \\
\text { Hasil } \\
\text { Simpanan }\end{array}$ & $\begin{array}{l}\text { Saat menentukan besarnya } \\
\text { Nisbah bagi hasil ada } \\
\text { kesepakatan dan tawar- } \\
\text { menawar antara Nasabah dan } \\
\text { BMT, sehingga saling rela } \\
\text { dan saling percaya. }\end{array}$ & $\begin{array}{l}\text { Fatwa } \\
\text { No.02/DSN- } \\
\text { MUI/IX/2000 } \\
\text { Tentang Tabungan }\end{array}$ & \\
\hline 2 & $\begin{array}{l}\text { Metode } \\
\text { Bagi Hasil } \\
\text { Simpanan }\end{array}$ & $\begin{array}{l}\text { Metode yang digunakannya } \\
\text { adalah metode Profit sharing }\end{array}$ & $\begin{array}{l}\text { Fatwa DSN No.15 } \\
\text { /DSNMUI/IX/2000 } \\
\text { tentang Prinsip }\end{array}$ & Sesuai \\
& & $\begin{array}{l}\text { Hasil Usaha dalam } \\
\text { Lembaga Keuangan } \\
\text { Syariah }\end{array}$ & \\
& & & \\
\end{tabular}


Sumber : data diolah peneliti

Bersarkan hasil analisis diatas menunjukan bahwa nisba bagi hasil pada Koperasi Syari'ah BMT Asy-Syabaab BKPRMI Pinrang sudah sesuai dengan Fatwa Dewan syariah Nasional (DSN) No.02/DSN-MUI/IX/2000. metode bagi hasil dan perhitungan bagi hasil sudah sesuai dengan Fatwa Dewan syariah Nasional (DSN) No.15/DSN-MUI/IX/2000. Di mana penentuan nisba di tentukan berdasarkan kesepakatan tawar menawar sehingga terjadi saling rela dan saling percaya. Metode perhitungan bagi hasil pada Koperasi Syari'ah BMT Asy-Syabaab BKPRMI Pinrang Menggunakan Profit sharing dimana kentungan yang di bagi hasil adalah keuntungan dikurangi biaya-biaya yang di keluarkan.

\section{PENUTUP}

Prosedur Simpanan di Koperasi Syari'ah BMT Asy-Syabaab BKPRMI Pinrang dilakukan dengan beberapa tahap seperti mengisi Formulir tahap ini Nasabah datang ke BMT dan membawa persyaratan yang di butuhkan. Sistem Bagi Hasil dan Perhitungannya yang diterapkan oleh Koperasi Syari'ah BMT Asy-Syabaab BKPRMI Pinrang pada Simpanan nasaba masih menggunakan metode Profit sharing berdasarkan Fatwa DSN No.15/DSN-MUI/IX/2000 Dalam Pembagian Hasil. Sedangkan dalam penetapan pembagian Nisbah bagi hasil telah ditetapkan oleh BMT dan Nasabah (Kesepakatan). Pendapatan bagi hasil yang diperoleh untuk masingmasing anggota/nasabah selalu berbeda, tergantung pada jumlah saldo tabungan dan keuntungan

BMT, karena besarnya saldo tabungan dan keuntungan BMT selalu berubah tiap bulannya.

\section{DAFTAR PUSTAKA}

Adiwarman, Karim, 2006, “ Bank isiam : Analisis Fiqh dan Keuangan, Edisike 3”, Jakarta: Raja Grafindo Persada. 2010, “Bank islam: Analisis Fiqh dan Keuangan”, Raja Grafindo Persada, Jakarta.

Ahmad Syifaul Anam, Problematika Penerapan Hukum Jaminan di Lembaga Keuangan Mikro Syariah, Seamarang: Rafi Sarana Perkasa, 2012.

Antonio, Muh. Syafi'i, 2001, “Bank Syari'ah: Dari Teori ke Praktik, Gemalnsani Press, Jakarta. Biro Perbankan Syari'ah, Bank Indonesia, 2003, "Pedoman Akuntansi Perbankan Syari'ah Indonesia (PAPSI) ” Jakarta.

Dendawijaya, Lukman, 2005, "Manajemen Perbankani Ghaiia indonesia" Bogor : Ghalia Indonesia,.

Djumhana, Muhammad, 2000, “ Hukum Perbankan di Indonesia ”, Bandung: CitraAditya Bakti. Esy Nur Aisyah, 2008, “ Penerapan Standar Operasional Prosedur dan Sistem Bagi Hasil Pada Tabungan Mudharabah (Studi Pada BMTMMU Cabang Wonorejo Pasuruan)”, Skripsi UIN Sunan Kalijaga.

Fatwa Dewan Syariah Nasional Nomor 02?DSN-MUI/IV/2000, “Tentang Tabungan, diakses pada tanggal 14 Januari 2014 http://www.badilag.net/data/FATWA\%20MU|\%20EDIT/2\%20tabungan.html. 
Ghafur, Muhammad, 2003, "Pengaruh tingkat Bagi Hasil, Suku Bungadan Pendapatan Terhadap Simpanan Mudharabah (Studi Kasus BankMuamalat Indonesia", Jurnal Ekonomi Muamalah, Universitas Gajah Mada.

Kasmir, 2003, "Bank dan Lembaga Keuangan Lainnya”, Jakarta : Raja Grafindo Persada. ,2008, “Analisa Laporan Keuangan” Jakarta: Rajawali Pers. 2009, “Manajemen Perbankan, Jakarta: Raja Grafindo Persada.

Khikmatul Mauia, 2012, "Pengaruh iingkat Suku Bunga, jumlah Bagi Hasil, inflasi, indeks Saham JII, dan Jumlah Uang Beredar terhadapDeposito Mudharabah Pada Bank Syari'ah Mandiri Periode 2007-2011".

Muh. Ridwan, 2004. Manajemen Baitul Maal wa Tanwil (BMT), Yogyakarta: UII Press

Muhammad, 2000, “Manajemen Bank Syari'ah”, Yogyakarta: UPP AMP YKPN.

Muhammad Sholahuddin, 2011, "Kamus Istilah Ekonomi Keuangan danBisnis Syari'ah", Yogyakarta: Raja Graindo Persada.

Nurqadri Yanmar Syam, 2012, “Analisis Pengaruh tingkat Bagi Hasil Terhadap Pembiayaan Pada Perbankan Syari'ah Di Sulawesi Selatan Priode 2004-2011”. Skripsi Universitas Hasanuddin.

Ratna Priatin, 2005, "Faktor-Faktor Yang Mempengaruhi Motivasi Menabung Di BPR Syari'ah Bangun Derajat Warga Yogyakarta Tahun2004”, Skripsi Fakultas Ekonomi, UII.

Samsul Ma'arif, 2009, “Analisis Perhitungan Sistem Bagi Hasil PadaTabungan Mudharabah (Studi Pada BRI Syariah Cab. Malang)”,'Skripsi UIN Sunan Kaiijaga.

Siamet Margono SH, 2008, "Pelaksanaan Sistem Bagi Hasil Pada Bank Syariah (tinjauan Umum Pada BTN Syariah Cabang Semarang)"

Slamet, Taufan, 2013, "Memahami Akuntansi Syari'ah di Indonesia”, Jakarta : MitraWacana Media,.

Sudarsono, 2003, "Bank Lembaga Keuangan Syari'ah: Deskripsi dan ilustrasi”, Yogyakarta: Ekonisia.

Sugiyono, 2008, "Metode Penelitian Bisnis", Cetakan Kedua Belas 2008, Bandung: Alfabeta, 2011, "Metode Penelitian Kuantitatif, Kualitatif dan R\&D", Bandung: Alfabeta,

Sumar'in, Ko nsep Kelembagaan Bank Syariah, Cetakan Pertama, Yogyakarta: Graha Ilmu, 2012. 